\title{
INTRODUCTION
}

The Moral Urgency of Anna Karenina

Gary Saul Morson

\section{The First Sentence}

Often quoted but rarely understood, the first sentence of Anna Karenina"All happy families resemble one another; each unhappy family is unhappy in its own way" - offers a paradoxical insight into what is truly important in human lives. What exactly does this sentence mean?

In War and Peace and in a variant of Anna Karenina, Tolstoy quotes a French proverb: "Happy people have no history." Where there are dramatic events, where there is material for an interesting story, there is unhappiness. The old curse - "May you live in interesting times!" - suggests that the more narratable a life is, the worse it is.

With happy lives and happy families, there is no drama to relate. What are you going to say: they woke up, breakfasted, didn't quarrel, went to work, dined pleasantly, and didn't quarrel again?

Happy families resemble one another because there is no story to tell about them. But unhappy families all have stories, and each story is different.

\section{Love and Fate}

We tend to think that true life is lived at times of high drama. When Anna Karenina reads a novel on the train, she wants to live the exciting incidents described, and both high literature and popular culture foster the delusion that ordinary, prosaic happiness represents something insufferably bourgeois. It may seem like a suspension of real living. Forms as different as romantic drama, adventure stories, and tragedies suggest that life is truly lived only in moments of great intensity. Tolstoy thought just the opposite.

The dramatic understanding of life that Tolstoy rejected has, if anything, grown still more powerful. Today few people question that "true love" is the grand and glorious feeling that consumes one's very being, as in Romeo and Juliet and countless debased imitations. By contrast, Tolstoy wants us to recog- 
nize that romantic love is but one kind of love. It is an ideology of love we do not recognize as such. Kitty at first prefers the dashing and romantic Vronsky to the kind and staid Levin because she has assumed, as most of us do, that she should marry the one she "loves"; and she has been told that "love" is romantic rather than prosaic. She does not yet recognize that what she feels for Levin is also a form of love, and that she has a real choice. Which love does she really want?

Over time she comes to recognize that in addition to romantic love there is also intimate love. Only intimate love is compatible with a family. Tolstoy wants his readers to be aware that this choice exists for them as well.

The myth embodied in great romances tells us that love envelops our whole being. Romantic love presses upon us with irresistible intensity. It transcends all ordinary prosaic conditions and lifts lovers to a realm of resplendent meaning. All-consuming, it allows no room for anything else. Lovers love not so much each other as love itself.

What is more, we do not choose such love, it befalls us. We "fall in love," we do not jump in love. Such love is a "passion," not an action. It is something we suffer, an idea figured in medieval literature by love potion and in modern thought by unconscious forces overwhelming the will.

For this reason, romantic love feels like fate, and an ideology of amoral fatalism often accompanies it. The lovers live in a realm beyond good and evil. After all, good and evil depend on choice, and where fate governs, choice is out of the question. No matter how much pain the lovers cause, one cannot condemn them. Adultery becomes as noble as revolution, and only narrow moralists worry about the pain caused the betrayed spouse or abandoned children.

That is the story Anna imagines she is living. As one of her friends observes, she resembles a heroine from a romance. But Anna's story is not Tolstoy's. He places his romantic heroine not in a romance, where her values would be validated, but in the world of prosaic reality, where actions have consequences and the pain we inflict matters.

Many besides Oprah Winfrey have read Anna Karenina as a celebration of its heroine and of romantic love, but that is to get the book exactly wrong. It is to mistake Anna's story of herself for Tolstoy's. As Anna Karenina imagines herself into the novel she reads, such readers imagine themselves as Anna or Vronsky. They do not seem to entertain the possibility that the values they presume are the ones Tolstoy wants to discredit.

Perhaps such readers simply presume that no great writer would take the side of all those shallow moralists. Would a great writer endorse what we dismiss as bourgeois living? But in an unexpected way, that is what Tolstoy does. He shows with unprecedented psychological subtlety why if any view is shallow, it is the romantic one. 
Anna's story illustrates the dangers of romantic thinking. As she gives herself to an adulterous affair, she tells herself that she had no choice, but her loss of will is willed. Returning by train to Petersburg with Vronsky in pursuit, she experiences a sort of delirium:

She was constantly beset by moments of doubt as to whether the car was going forward or back or standing still altogether. Was it Annushka beside her or a stranger? "What is this on my arm, a fur or a beast? And is this me here? Am I myself or someone else?" She was terrified of surrendering to this oblivion. But something was drawing her into it, and she could surrender or resist at will. (part I, chapter 29)

The relativism of motion she experiences feels like the delirious moral relativism she is falling into. Though she will later insist she could not have done otherwise, "she could surrender or resist at will." Her fatalism is a choice.

Later, when Dolly comes to visit her, Anna pleads inevitability to excuse her affair, the pain she has caused her husband, and the abandonment of her son. She argues that choice is an illusion and so blame is never appropriate. "But I was not to blame," she tells Dolly. "And who was to blame? What does it mean to be to blame? Could it really have been any other way? Well, what do you think? Could it have happened that you did not become Stiva's wife?" (part VI, chapter 23).

\section{Omens}

Anna feels that fate has marked her out for a special destiny, perhaps tragic but surely exalted. When we first see her at the station in part I, a trainman is accidentally crushed. With a shudder Anna tells Stiva: "It's a bad omen," and she means, "a bad omen for me" (part I, chapter 18). This comment, in other words, proceeds not only from fatalism but also from narcissism. After all, even if the event were an omen, how does she know it refers specifically to her among all the countless people present?

An omen is a sign from the future. A later event sends a sign of its approach to an earlier time, and so omens involve backward causation. For a future event to have such causative power, it must already in some sense exist. It is somehow already there, the way a place we are traveling to, but cannot yet see, is already there.

If there are omens, then the world resembles a literary work with foreshadowing, which also entails backward causation. The very term "foreshadowing" derives from a spatial metaphor for time. If we are walking down a curved path, we may see the shadow of an object before we see the object casting the shadow, and so the sign precedes its cause. Omens and foreshadowing treat time in 
this way. They treat the future as not dependent on present choices but already given.

Anna repeatedly experiences a terrifying dream of a peasant with a sack saying incomprehensible French words. She takes this dream for another omen. On one occasion she wakes from this dream into another, in which she is told that the inner dream means she will die in childbirth. When Vronsky tries to persuade her to take some step to alter their position, Anna replies that there is no need to do anything since she is fated to die in childbirth. For Anna, fatalism excuses not only her actions but also her inactions.

The fact that Anna survives childbirth does not in the least shake her faith in omens and fatalism. In part VII, when she is in despair at the train station, the sight of a peasant reminds her of her dream. And "suddenly, recalling the man who was crushed the day she first met Vronsky, she realized what she had to do" (part VII, chapter 31). It is crucial to understand this passage. Anna's decision results not from fate but from her own fatalism. The omen is fulfilled only because she chooses to fulfill it.

Tolstoy is not using foreshadowing here, a device he avoided as incompatible with realism. The agency for Anna's death is not the author's but the character's. It results from her mistaken view of the world.

\section{What We Do Not See}

Anna interprets the dream of the hideous peasant as a sign from the future, but Tolstoy shows us that it results from ordinary causality operating from the past. The images of the dream derive either from previous dreams or from events connected with meeting Vronsky. Some occur at the train station, where she first sees him, others on the train ride home. They become fused with her feeling that she is doing something terribly wrong. Her guilt fuels the dream's sense of terror. But why doesn't she recognize the source of the dream's images?

The answer reflects Tolstoy's sense of how the mind works. We see much more than we remember seeing. Events happening at the periphery of our attention and scarcely noticed may recur to us without our awareness of their source. When the train stops, passengers get out:

The dashing conductor, giving a whistle while still moving, jumped down, and behind him impatient passengers began getting off one by one: a Guards officer holding himself erect and looking around sternly; a restless merchant carrying a valise and smiling cheerfully; a peasant with a sack over his shoulder. (part I, chapter 17)

Anna's dream incorporates and transforms this peasant, but of course she will never remember that she saw him. Neither does the reader. What she sees but 
does not notice, we read and do not remember. I have taught this novel to more than ten thousand students, and not one has ever noticed this passage or remembered reading it; so far as I know, the same is true of the critics as well. But unless they were skimming, they must have.

The crucial difference between Anna's experience and the reader's is that the reader can go back and check. We can reread earlier portions of a novel as we cannot reexperience earlier moments of our lives. This novel encourages us to grasp how often we miss things right before our eyes.

Tolstoy is always showing us: we do not see the world, we overlook it. He wants to reeducate us to perceive the world differently, so that we are capable of understanding what passes before our eyes hidden in plain view.

\section{Tiny Alterations}

In an essay about War and Peace, Tolstoy evokes the image of a man seeing nothing but treetops on a distant hill and concluding fallaciously that the hill contains nothing but trees. Of course, had he actually visited the hill and seen it up close, countless houses and people might have presented themselves. In much the same way, historians conclude that in bygone times only dramatic events were taking place since those are the only ones people bother to record. In short, we tend to think of life as consisting primarily of noticeable events precisely because those are the ones we notice.

In Tolstoy's view, that view is precisely wrong. Life consists primarily of the countless ordinary events always occurring. In one of his later essays, he retells the story of the painter Bryullov, who corrected a student's sketch. "Why you only changed it a tiny bit, but it is quite a different thing," the student exclaimed. Bryullov replied: "Art begins where that 'tiny bit' begins." Tolstoy explains:

That saying is strikingly true not only of art but of all life. One may say that true life begins where the tiny bit begins - where what seem to us minute and infinitesimally small changes occur. True life is not lived where great external changes take place - where people move about, clash, fight, and slay one another-it is lived only where these tiny, tiny, infinitesimally small changes occur. ${ }^{1}$

Better than anyone else who ever lived, Tolstoy traces the infinitesimally small changes of consciousness. That, perhaps, is the key to the impression of so many readers that his works feel not like art but like life, that if the world could write directly, it would write like Tolstoy.

There are only two passages in world literature that make Christian lovelove not just for one's neighbors but for one's enemies - psychologically plausible. One occurs in War and Peace, when Prince Andrei loves his enemy Anatol 
Kuragin, and the other in Anna Karenina, when Karenin, who has hated Anna and wished her dead, is moved to genuine Christian love and forgiveness. Even Dostoevsky was never able to do more than assert the existence of such love. How does Tolstoy make it truly believable?

Briefly put, Tolstoy breaks the process of consciousness into finer and finer pieces. Where most good writers would see the movement from one state of mind to another as a single step, Tolstoy identifies many more steps along the way. When we read his descriptions, we recognize that we have experienced such infinitesimally small steps even if we would not otherwise remember them. We grant the plausibility of each small step he describes and so find ourselves at the final one.

For Tolstoy, art worthy of the name requires learning to notice details easily overlooked. Mikhailov, the painter we meet in part V of Anna Karenina, no longer notices such noticing because it has become habitual: "He himself did not notice how, approaching them, he seized upon and assimilated this impression, just as he had the jaw of the merchant who had sold the cigars, and hid it away to be brought out when the need arose" (part V, chapter 10). Acquiring this habit of perception is the real work of the artist. Vronsky and Golenishchev attribute the quality of Mikhailov's art to "technique," but Mikhailov himself is aware that he is not especially gifted that way. "If what he saw had been revealed to a small child or to his cook, she would have been able" to paint as he $\operatorname{did}($ part $\mathrm{V}$, chapter 11).

\section{Open Camouflage}

As if to demonstrate how we often overlook key facts right before our eyes, Tolstoy often places them in subordinate clauses of long sentences or in the middle of paragraphs primarily about something else. Having forgiven Anna, Karenin dotes on her daughter, and in the middle of a long paragraph we read, but easily miss, something immensely important:

At first from a feeling of compassion alone he took an interest in the rather weak newborn girl who was not his daughter and who had been abandoned during her mother's illness and who surely would have died had he not taken an interest in her-and himself did not notice how he had come to love her. Several times a day he went to the nursery and sat there for long stretches of time so that the wet nurse and nurse, who at first were shy in front of him, became accustomed to him. (part IV, chapter 19)

"Who would surely have died if he had not taken an interest in her": the little girl owes her life to Karenin. He is the only character in this novel who saves a 
life. And yet this remarkable fact appears in the fourth of five clauses - the least prominent position possible - and the next sentence deals with something else. I know of no critic who has remarked on this passage, yet surely it should make an enormous difference in our evaluation of Karenin.

Anna will repeatedly say how horrible her marriage was, but we are given ample evidence to the contrary. In part II, Karenin tries to talk with Anna about her ostentatious flirtation with Vronsky, but she fends off all attempts at conversation with a feigned "cheerful bewilderment" about what he could possibly mean. Anna "was herself surprised, listening to herself, at her ability to lie. ... She felt as if she were wearing an impenetrable armor of falsehood." The next paragraph begins:

Her look was so simple, so cheerful, that anyone who did not know her as her husband did would never have noticed anything unnatural in the sounds or the sense of her words. But to him, knowing her, knowing that when he went to bed five minutes later than usual she noticed and asked the reason, to him, knowing that she immediately informed him of any joy, happiness, or grief, to him to see now that she did not want to remark on his state, that she did not want to say a word about herself, meant a great deal. (part II, chapter 9)

When he went to bed five minutes later than usual, she noticed and asked the reason; she shared any joy, happiness, or grief with him: surely this was a marriage as good as or better than most! Yet readers and critics repeatedly miss this information and accept Anna's later false memories as accurate.

Time and again, Tolstoy uses this technique of open camouflage. He does so, I think, so that we learn not to equate noticeability with importance and so that we acquire, bit by tiny bit, the skill of noticing what is right before us.

\section{Gold in Sand}

Anna Karenina interweaves two major stories-Anna's and Levin's-but it is the novel's third story, concerning Dolly and Stiva, that offers the book's moral compass. If by the hero or heroine of a novel we mean not the one who occupies the most dramatic space but the one who best embodies the author's values, then the real hero of Anna Karenina is Dolly. Her everyday goodness, her ceaseless efforts for her children, and her fundamental decency attract little attention, but they are, from Tolstoy's perspective, the most meaningful possible activities. Here, as in many other works, Tolstoy teaches that we do not notice the really good people among us.

If a life well lived is one without major events, how does one write a novel about it? Tolstoy's solution is to put the life based on mistaken values - Anna's- 
in the foreground, while Dolly's virtues and troubles remain in the background, where they can easily be missed. Readers, critics, and filmmakers often treat Dolly as nothing more than a boring housewife - merely a good mother, as Stiva thinks of her-but for Tolstoy nothing is more important than a good mother. Life's most important lessons are acquired in childhood or not at all. Vronsky will always remain a shallow individual because, as Tolstoy explains, he never had a family life. Parenting truly matters.

Perhaps the novel's key moment belongs to Dolly. She finds herself in the country with her children in a house that Stiva has promised but neglected to make suitable for them. At last, she manages to get things in order,

and for Darya Alexandrovna her expectations were being fulfilled of a comfortable, if not peaceful, country life. Peaceful with six children Darya Alexandrovna could never be. . . But in addition, however hard it might be for a mother to bear the fear of illnesses, the illnesses themselves, and the grief at the sight of signs of bad tendencies in her children, the children themselves were even now repaying her sorrows with small joys. These joys were so small they passed unnoticed like gold in sand, and in bad moments she saw only the sorrows, only the sand; but there were good moments, too, when she saw only the joys, only the gold. (part III, chapter 7)

Gold in sand: that is what true happiness is like. It occurs at ordinary moments and does not call attention to itself, much as Dolly does not call attention to herself. And yet it is moments like these that make a life meaningful.

If one were to offer a plot summary of the novel, this scene would probably not appear. It, too, is openly camouflaged.

\section{Stiva}

If Dolly represents what goodness is, then her husband Stiva represents what evil-most, if not the worst, evil-truly is. And the first thing to notice about evil is that it is not as ugly as sin but as attractive as pleasant company. That is why there is so much of it. We have met the enemy and he is us. Evil is not alien, but resembles ourselves, because we are most responsible for it.

Stiva is immensely charming, and so everyone likes being with him. What's more, he does not have a shred of malice. Tolstoy wants us to appreciate that most evil results not from active hostility but from mere neglect, something like criminal negligence. It is largely negative, an absence, a forgetting. It is caused primarily by what we don't do. And so we can easily be responsible for it while thinking well of ourselves. When Stiva forgets to fix up the country house for 
Dolly, Tolstoy remarks: "No matter how hard Stepan Arkadyevich tried to be a concerned father and husband, he never could remember that he had a wife and children" (part III, chapter 7).

Stiva is the perfect hedonist, totally immersed in the pleasures of the moment. When he is with Levin, he encourages his pursuit of Kitty with some German verses, and only a few pages later he encourages Vronsky's pursuit of Kitty with the very same verses. In doing so, Stiva is not exactly lying, if by lying we mean telling a conscious falsehood. It is simply that when he is with Levin, he sincerely sympathizes with him, and when he is with Vronsky, he sincerely sympathizes with him. The dishonesty lies in what he does not do: he does not check his memory to find the discrepancy. Stiva can sincerely think of himself as truthful because for him each present moment is entirely discrete. It binds him to nothing. When he sees Dolly's misery over his affair, his heart goes out to her, but that will not preclude him from endless future affairs.

It is not exactly that Stiva has a bad memory. Rather, he has an excellent forgettory. Appreciating that guilt, regret, and other unpleasant memories distract from the pleasures of the moment, he has taught himself to banish them from his mind. As the novel proceeds, we watch his progress in forgetting. He keeps selling off Dolly's property to indulge his pleasures while she tries harder and harder to fend for the children he forgets about.

\section{Self-Deception}

Families in Tolstoy's novels are not collections of individuals who happen to be related but distinct miniature cultures. Each family appreciates the world in its own way. The Shcherbatskys understand the world in terms of family life. The Oblonskys are quite different, and the first thing to understand about Anna is that she was born Anna Oblonskaya.

Like Stiva, Anna commands an amazing receptiveness to the people in front of her. When she wants to, she can make herself the perfect listener, which is how she manages to persuade Dolly to forgive Stiva for his affair. Her manipulation is both skillful and deliberate.

Stiva is anything but weighed down with remorse, much less repentant. The novel opens with him waking from pleasant dreams about feasts and women, and he calls himself honest because he is incapable of feeling any guilt over what he has done. Yet Anna tells Dolly just the opposite: "He is wretched, remorse is killing him." Dolly is dubious: "Is he capable of remorse?" she asks. Anna replies:

"Yes, I know him. I could not look at him without pity. We both know him. He is good but he is proud, and now he is so humiliated. What 
touched me most" - and here Anna divined the main thing that could touch Dolly - "he's tormented by two things: he's ashamed for the children's sake, and while loving you ... yes, yes, while loving you more than anything in the world ... he hurt you, destroyed you." (part I, chapter 19)

"Here Anna divined what would touch Dolly most": her guesses at such moments are unerring, and she says what she needs to. That, indeed, is why Stiva has summoned her to patch up the quarrel.

But Anna differs from Stiva in one important respect. She has a conscience. She feels terrible guilt for her affair and the pain it causes her husband. Her response to this guilt constitutes one of the book's most remarkable psychological studies.

To escape from conscience, Anna practices an elaborate process of selfdeception. So insightful is Tolstoy's description of this process that this novel could well be the touchstone for any study of lying to oneself. How is it possible both to know something is true and yet to convince oneself that it is false? Wouldn't the falsehood be palpable and thus unbelievable? We are so familiar with self-deception, and we all practice it so often, that we often forget how perplexing a phenomenon it is.

Self-deception takes time. One cannot just command oneself to believe something one knows is untrue. Rather, one accomplishes the process in tiny steps. At any given moment, one can see another person in a small range of ways, depending on whether one focuses on his attractive or unattractive qualities and on whether one chooses to see him generously or ungenerously. Within that range, one can choose how to direct one's attention. That choice matters. By constantly focusing on the person's worst qualities, one can gradually shift the range so that what was once at the extreme of hostility comes to lie in the middle. If one repeats the process long enough and often enough, one can come to see the person more and more unfavorably without any obvious sense of lying. To be sure, at any point one could make an effort to check one's current impressions against earlier more favorable views. But that is an effort the self-deceiver refrains from making.

Because Anna feels guilty for hurting her husband, she convinces herself that he cannot feel. She knows better, and is well aware that although he cannot express his feelings, he nevertheless experiences them. He suffers horribly from jealousy. But she makes sure not to see his suffering.

Tolstoy tells us that Anna "schooled herself to despise and reproach him" (part III, chapter 23). She maintains of him that "this is not a human being, this is a machine" (part II, chapter 23). Since Tolstoy cannot show countless acts of hostile looking, he depicts actions that imply them: on two occasions, Anna 
mimics Karenin's gestures and speech perfectly. How much hostile looking does it take to do that?

Karenin has set one condition for Anna to continue her affair with Vronsky, that she not meet her lover in their house. That condition hardly seems especially arduous, but Anna violates it anyway, and Karenin encounters Vronsky in the doorway. When Vronsky describes what happened, Anna responds with practiced mockery:

"And he bowed to you like this?"

She made a long face, and half-closing her eyes, quickly changed the expression of her face and folded her hands, and Vronsky suddenly saw in her handsome face the very expression with which Alexei Alexandrovich had bowed to him.

Vronsky wonders, "How can he bear this situation? He's suffering, that is obvious," but Anna denies that he is capable of suffering at all:

"He?" she said with a grin. "He's perfectly content." ...

Again she could not help but mimic him. "Anna, ma chère, Anna dear!

"He's not a man, not a human being, he's a puppet!" (part IV, chapter 3)

Anna's pretense breaks down when she thinks she is dying in childbirth. Apparently at the point of death, she renounces all her falsifications and admits to having deliberately altered her impressions of her husband. Before she realizes Karenin has arrived, she says of him: "He is good, he himself does not know how good he is. . . Y You're just saying he won't forgive me because you don't know him. No one knew him. Only I do, and it was hard even for me" (part IV, chapter 17).

When at last Anna sees Karenin, she describes her negative views of him as an effort at falsity:

“Yes, yes, yes. Here is what I wanted to say. Don't be surprised at me. I'm still the same. . . . But there is another woman inside me, and I'm afraid of her - she loved the other man, and I wanted to hate you and couldn't forget the woman who had been before. I'm not her. Now I'm the real one." (part IV, chapter 17, ellipsis in text)

When Anna recovers and again wants to take up with Vronsky, she can no longer call her husband heartless, especially after his Christian conversion and his unqualified forgiveness of her. In that state of mind, he offers her a divorce 
and more. Under Russian law, the only grounds for divorce was adultery, and the adulterous party could not remarry. Karenin offers to plead that he is the adulterer so that Anna can marry Vronsky. He also offers her custody of both children. Later, Anna will say that she had to choose between her lover and her son, but that statement is palpably untrue, another sign of a memory repatterning the past. When readers accept that assertion, is their memory playing the same trick?

Anna herself makes it crystal clear why she refuses Karenin's amazingly generous offer. She explains to Vronsky: "Stiva says he has agreed to everything, but I cannot accept his generosity" (part IV, chapter 23). She does not wish to be indebted to him, to acknowledge his moral superiority. One might well ask how much she can love her son if that is the reason she chooses to leave him behind.

\section{Views}

Unlike the book's other educated characters, Levin thinks for himself. Instead of just adopting approved enlightened opinions, he actually learns both sides of an issue. When the progressive theories he adopts to modernize his farm and improve the peasants' lot fail, he does not, like his friend Sviyazhsky, change the subject or seek some ad hoc justification of progressivism. Rather, he admits his mistake and seeks some other solution, however unconventional it may be. How many intellectuals can ever admit their critics were right? In Tolstoy's view, Levin's intellectual honesty is vanishingly rare.

Most intellectuals resemble Stiva, who first decides which camp to join and then makes sure to learn only the arguments on that side.

Stepan Arkadyevich took and read a liberal newspaper.... And even though neither science nor art nor politics held any particular interest for him, he firmly maintained the same views on all these subjects that were maintained by the majority and by his paper, and he changed them only when the majority changed them, or, better put, he did not change them at all; they imperceptibly changed within him. (part I, chapter 3)

His views seem to change by themselves because Stiva never really thinks: he just arranges to believe what a liberal is supposed to believe. When liberal positions shift over the years, so do his, but without any of the agonized confrontation with disconfirming evidence that marks an authentic thinker like Levin.

Levin far prefers to exchange views with a landowner much more conservative than he because the landowner "obviously spoke his own original thought, something that rarely happens, and a thought to which he had been brought not by a wish to occupy an idle mind, but a thought that had grown up out of 
the conditions of his life, which he had considered in his rural solitude and had thought over in its every aspect" (part III, chapter 27).

Here and elsewhere, Tolstoy is concerned with how intellectuals think. Can they really be concerned with helping the poor peasants if they do not bother to consider whether their reforms will actually work? If they really cared about their professed aims, wouldn't they learn to consider contrary evidence and to invite criticism? Could it be that instead of helping the poor, their real concern is to think well of themselves? In focusing on the inauthenticity of the educated, Tolstoy disturbed intellectuals of his day-and ours.

\section{Daily Miracles}

Levin's experience, and the book he is writing, teach him that in the social and moral worlds, abstract thought tends to mislead. One must give precedence not to theory, as intellectuals typically do, but to what might be called the wisdom of practice. Theory properly serves as a sort of mnemonic device, a set of provisional generalizations from experience.

The same is true of conventional narratives. The stories we routinely tell about life typically leave out all those messy contingencies that characterize real experience. Levin comes to appreciate that the neater an account of experience, and the more it resembles a well-made story, the farther it departs from reality.

Levin has presumed an idyllic story of marriage. But Kitty, who understands the intimate love of good families, knows that story is as false as romance. In intimate love one's spouse is a less than ideal person whose thoughts and feelings are hard to appreciate. Such intimacy takes work and, until the couple come to know each other, it occasions quarrels.

Contrary to common opinion, the early days of a marriage are likely to be the hardest. Levin, with his idyllic views of marriage straight out of storybooks, is surprised at the prosaic truths that Kitty has known all along, but here, as elsewhere, he eventually comes to value Shcherbatsky wisdom:

Levin had been married nearly three months. He was happy, but not at all in the way he had expected to be. . . Levin was happy, but having embarked upon family life, he saw at each step that it was not at all what he had imagined. At each step he experienced what someone would experience who, having admired the smooth, happy progress of a little boat across a lake, should then actually get into that boat. He saw that it was not enough to sit there evenly without rocking; that one had to think, too, without forgetting for a moment where one was going, that beneath one's feet was water, and that one must row, and that his unaccustomed hands would hurt, and that it was only easy to look at, but doing it, though quite joyful, was also quite difficult. (part $\mathrm{V}$, chapter 14) 
Difficult delight resulting from constant hard work: that is what family love demands. The reward is knowledge of each other almost from within.

In part VIII, Levin falls into despair because he cannot answer the existential questions about death that trouble him. He reads the great philosophers, but they offer no help in his search for meaning in the face of all-devouring death. Tolstoy's description of Levin's state of mind - which had also been his ownremains one of his great triumphs.

Levin finds his way out of despair when he realizes that he must trust not to theory but to practice. "He had been living rightly but thinking wrongly" (part VIII, chapter 12). He needed to look not into the distance but at what he was already doing.

Levin lives rightly because he focuses not on Humanity or Russia or any other remote abstraction but on the people immediately around him. He tends to what is, as he says, incontestably necessary. He cares for the peasants, for the property of his sister, and for his immediate family. He could no more fail to do so than he could fling down a baby in his arms. There are some things we know more surely than we could justify theoretically; and anyone who needed a theory to tell him why he should not fling down a baby would be lacking something fundamental.

In his daily work, Levin comes to appreciate the importance of the ordinary and prosaic. If one lives rightly moment by moment, and trusts that daily practice has its own wisdom, then the questions troubling Levin are not exactly answered, but they disappear. When Levin recognizes these Tolstoyan truths, he is overcome with joy:

"I was looking for miracles, regretting that I had not seen a miracle that might convince me. But here is a miracle, the sole miracle possible, existing continuously, surrounding me on all sides, and I didn't notice it! . . I have discovered nothing. I have only recognized what I already knew. . . . I have been freed from falsity, I have found the Master." (part VIII, chapter 12)

In his time, Tolstoy was known as a nyetovshcik-one who says no (nyet) to what almost all educated people believe. If anything, his views are even more at odds with educated opinion today. In this novel's rejection of romantic love; in its challenge to the inauthentic ways intellectuals think; in its trust in practice over theory; and above all, in its defense of the prosaic virtues exhibited by Dolly - in all these ways, Anna Karenina challenges us today with ever-increasing urgency. 